Institute of $\mathbf{F}_{\text {ood and }} \mathbf{A}_{\text {gricultural }} \mathbf{S}_{\text {ciences }}$

\title{
Potential for Gossypol Toxicity When Feeding Whole Cottonseed to Beef Cattle 1
}

\section{R.O. Myer and L. R. McDowell ${ }^{2}$}

The feeding of whole cottonseed to beef cattle has increased over the last decade due to increased local cotton production. Whole cottonseed is a good source of both protein and energy for beef cattle rations. However, one should be aware of potential gossypol toxicity when feeding cottonseed.

\section{What Is Gossypol?}

Gossypol is a natural toxin present in the cotton plant that protects it from insects. Its name is derived from the scientific name of cotton (Gossypium spp.) and phenol, its main chemical structure.

Non-ruminant animals, such as pigs and poultry, can't tolerate much gossypol before toxicity signs develop. Cattle, however, have the ability to detoxicify gossypol because the microorganisms within the rumen bind it so it can't be absorbed. This ability, however, can be compromised at very high levels of cottonseed feeding. With young calves, the feeding of whole cottonseed is not recommended until they have a well-developed rumen (usually at over four months of age). Young calves will not eat enough cottonseed from the cow's ration to present a problem when lactating cows are supplemented at or below the recommended level.

\section{Feeding Guidelines}

Typical maximum recommended ration levels of whole cottonseed are $0.5 \%$ of body weight per day for mature cows and $0.33 \%$ of body weight for weaned calves. This would be about $5 \mathrm{lbs} / \mathrm{day}$ for a mature cow and $1.5 \mathrm{lbs} /$ day for a weaned calf (450 lbs). The maximum amount should not be exceeded, not only because of the gossypol content but also because of the high fat/oil content of whole cottonseed. If the recommended level is exceeded, diarrhea may result due to the high level of fat. In addition, care should be taken to ensure that individual animals do not over-consume cottonseed when group- fed.

\section{Gossypol and Bull Fertility}

In regards to bulls, gossypol can cause a temporary reduction in fertility when cottonseed is fed above the recommended level. Because of the importance of bull fertility to profitable beef production, the general recommendation is that bulls should not be fed whole cottonseed 60 to 90 days before the start of the breeding season. The feeding of whole cottonseed to the cow herd when the bulls are present is okay as any decrease in fertility will take several months to develop. By the time fertility

1. This document is AN130, one of a series of the Animal Science Department, Florida Cooperative Extension Service, Institute of Food and Agricultural Sciences, University of Florida. Original publication date April 2003. Visit the EDIS Web Site at http://edis.ifas.ufl.edu.

2. R.O. Myer, Professor of Animal Sciences, NFREC, Marianna, and L.R. McDowell, Professor of Animal Sciences, Department of Animal Sciences, Florida Cooperative Extension Service, Institute of Food and Agricultural Sciences, University of Florida, Gainesville, 32611. 
begins to decline (if at all), the breeding season

should be over.

\section{Summary}

Overall, whole cottonseed is an excellent supplemental feed for beef cattle. If fed properly, it should not cause any problems. Whole cottonseed offers the potential for cattle producers to save money, but the level of management will be slightly higher than with traditional supplements. 